\title{
昭和電工東長原工場におけるタンタル製錬
}

\section{Processing of Tantulum Metal at Higashi Nagahara Plant}

\author{
小松 昭 利 ${ }^{*}$ 小 恵 二** \\ Akitoshi KOMATSU Keiji KOYAMA \\ 内 藤 博 夫*** \\ Hiroo NAITO
}

\section{1. 緒 言}

当工場は福島県のほぼ中央部に位置し，その開設は明 治43年と非常に古い。

当工場の主力製品は塩素酸ソーダ，塩素酸力リ，タン タル，電解鉄，金属ナトリウムで約 300 名の従業員が働 いている。タンタルは昭和39年に中央研究所よりパイロ ットプラントの形で移設され，以来 3 年の間に月産 $1.0 \mathrm{t}$ 以上，国内における最大のメーカーに成長した。タンタ ルは規模は小さいが，内容は複雑である。それは製品の 用途が耐熱，耐食材向と電子工業向に分かれており，と くに電子工業向は焼結型電解コンデンサ用, 粉末として 使用されるため, より微視的な管理, 調整が要求される ためである。

製造工程の概略を第 1 困に示し, 次章にて各工程につ き詳述する。

\section{2. 製 造 法}

\section{$2 \cdot 1$ 原料処理工程}

タンタル鉱石 (タンタライト, マイクロライト), スク
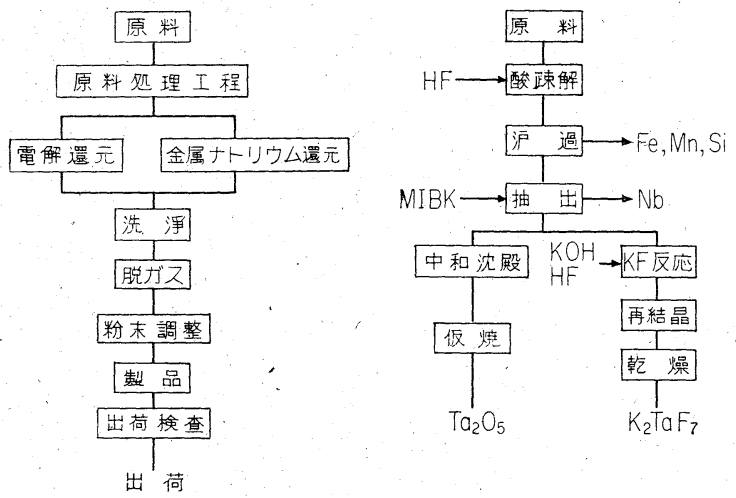

第1図 タンタル製造工程 概略図
ラップまたは還元工程よりの回収品などを出発原料とし て還元工程の原料である $\mathrm{K}_{2} \mathrm{TaF}_{7}$ ないし $\mathrm{Ta}_{2} \mathrm{O}_{5}$ を製造 する工程である。

鉱石処理はH F 疎解-MIBK 溶媒抽出（脈動抽出塔方 式）を採用しており，抽出塔を 2 基備え，その能力は， $\mathrm{K}_{2} \mathrm{TaF}_{7}$ として最大 $1,000 \mathrm{~kg} /$ 月 である。工程図を第 2 図に示す。

\section{$2 \cdot 2$ 雪解還元工程}

当初は治金用粉末の製造を目的としていたが昭和36年 より焼結型電解コンデンサ用粉末の製造もその目的に加 え, 電解条件の改良, および粉砕法の検討により 38 年に 一応技術的確立在みた。

当社の電解条件は $\mathrm{K}_{2} \mathrm{TaF}_{7}$ を支持塩として $\mathrm{Ta}_{2} \mathrm{O}_{5}$ を 原料とし陽極に黒鉛ルツボを使用して, 電解電圧 7 10 $\mathrm{V}$, 電解温度 $800 \sim 900^{\circ} \mathrm{C}$ を採用し, 生産能力は $300 \mathrm{~kg} /$ 月である。電解法の久陷である低原単位は付着塩の粉砕 回収等により改善された。また品質的には粉砕と洗浄の 組合せにより，電解品としては最高の純度（とくに $\mathrm{C} \leq$ $50 \mathrm{ppm}$ ）を実現した。

コンデンサ用粉末としては, ナトリウム還元粉のよう
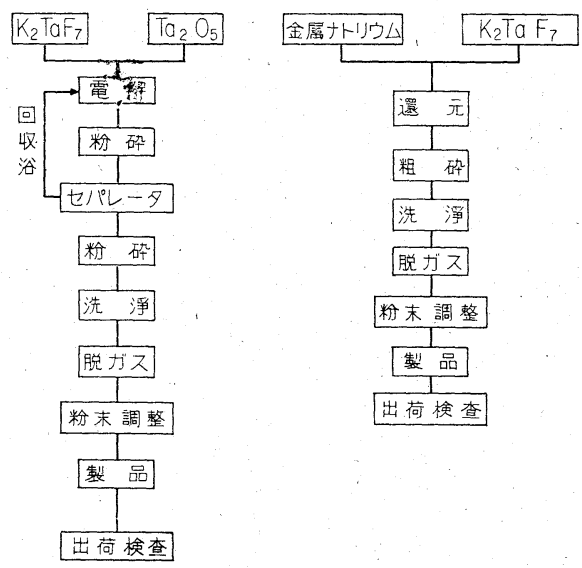

第 3 図 電解還元工程

第 4 図金属ナトリウム還 元工程 


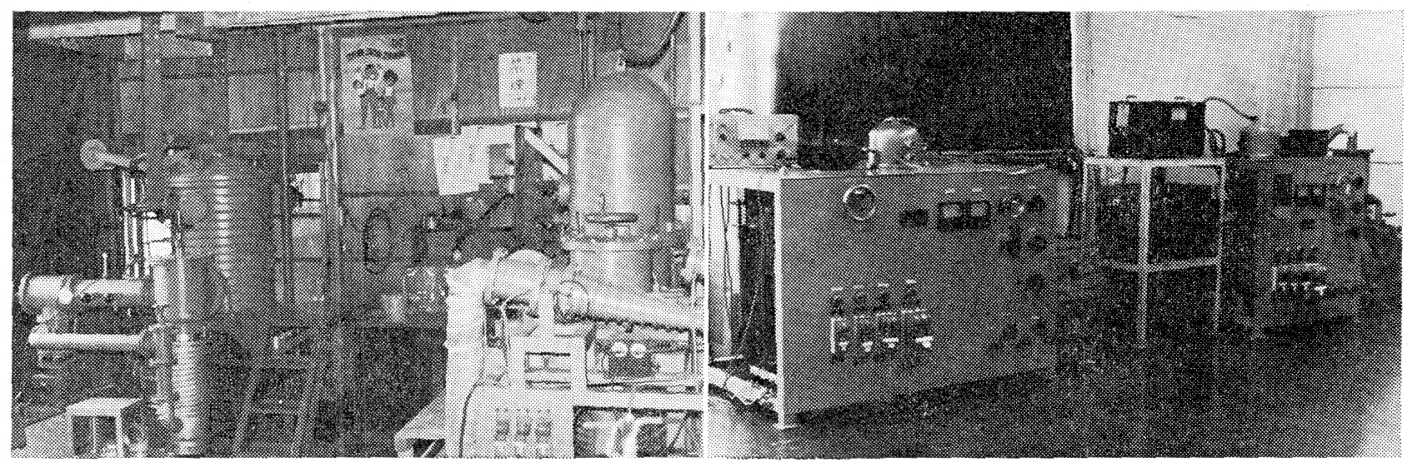

写真1 脱ガス炉

に超高容量級までは無理であるが，粉砕法を検討するこ とにより中容量級から低容量級まで，とくに耐圧性の高 以分野に执いて電解粉の特徵吕発揮された。本工程の工 程図を第3图に挙价る。

\section{$2 \cdot 3$ 金属デトリウムに上る $\mathrm{K}_{2} \mathrm{TaF}_{7}$ 還元工程}

当工場は金属ナトリウムの製造も行なつているので活 性の高い金属ナトリウム走還元剤とする本製造方法の立

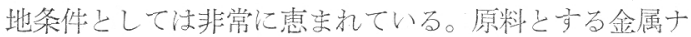
トリウムは通常の市販品をさらに精製したものでの C, $\mathrm{N}, \mathrm{O}$ 含有量が非常傒尔くなつている。本工程の工程 図学 4 図佂示す

燒結型コンデンサ用タンタル粉末位その粉末特性およ び㙓結特性が製品グレードごとに一定の範田に管理され ていることが必要で㐫る。

本工程に都いて，粉未の諸特性老決定的に支配古るの は還元反応である。すなわち還元温度和よび反応速晊が 生成粉末物性を決定する最も大きな因子である。当社は これらの還元条件を爰密にコントロールすることによ り，目標グレードの粉末物性を有する粉末圭任意に製造 子る技術意確立した。な扮後段の粉末調整操作において 還元反応の多少のバラツキを充分吸收しているので製品 に晾少バラッキは小さい。

そのほか本工程, とくに洗浄工程に执いてタンタルの ロス学できるだけ下げることにより歩留 $98 \%$ を達成して いる。本工程の製造能力江, $000 \mathrm{~kg} /$ 月である。

\section{$2 \cdot 4$ 脱才珪}

洗浄工程経た粉末は当然 $\mathrm{H}_{2}$ ガス多量に吸蔵して いるので号の脱ガス，精製字行なら工程である。炉真 空内熱型で脱ガス效率を上げるため棚段式を採用してお り，脱力゙ス条件は压力 $5 \times 10^{-5} \mathrm{mmHg}$ 以下，加熱温度 $\max 1,800^{\circ} \mathrm{C}$ で, 現在 3 基索備光処理能力はmax $50 \mathrm{~kg} /$ Batch である。ガス放出時の大量の $\mathrm{H}_{2}$ ガスを短時間に 排気するために，メカニカルブース夕を装備している。 な拉本工程の $\mathrm{H}_{2}$ ガス放出は $700 \sim 900^{\circ} \mathrm{C}$ で完了するが, 単なるガス放出のみでなく，粉未の燒結特性を改善する

写喜 2 タンタルアノード暁結炉 ための処理を含んでいるので加熱温度, 時間の管理は重 要である。

\section{$2 \cdot 5$ 粉末調整工程}

電解コンデンサの比静電容量は誘電体の表面積（この 場合はタンタル焼結体の全有効表面積) に比例与る。乙 たがつて比静電容量の安定した粉末にするためには粉末 の比表面積を一定に調整するのみでなく，粒形，粒度分 布および縆度など焼結特性に影響する諸因子をすべて管 理しなければならない。この点に打いて一般の粉末治金 用原料粉末よりさらに微視的な調整が要求される。

\section{$2 \cdot 6$ 福查工程}

タンタル粉末の検査は一般の粉末乙同樣に不純物含有 量, 粒度, 粒度分布, 比表面積 (严均粒径), 加密度な ど妾測定するが、コンデンサ用粉末の場合は上記の他に

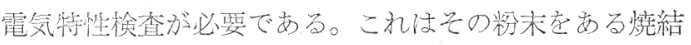
条件で燒結体とした場合にいかなる品質のコンデンサに

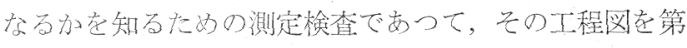
5 图比举师る。

通常の定常出荷に際しては1次测定值在用いるが，最 近の高品位コンデンサ製造用原料粉末に效してはコンデ ン年製品まで仕上げて，その特性をチェックしなければ ならない。しかしこの製品化工程はコンデンサメーカー

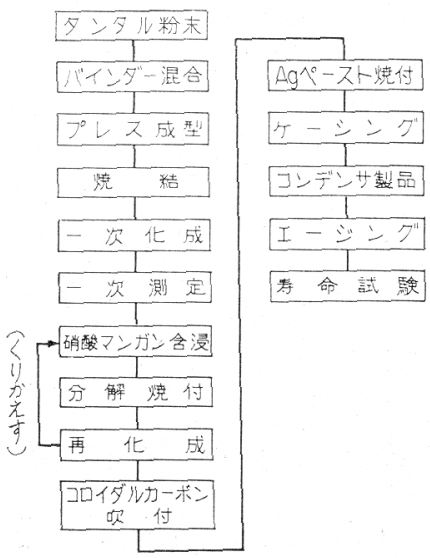

第 5 図

タンタル電解コン デンサ製造工程 
小松・小山・内藤：昭和電工東長原工場

それぞれに各社独自の方法があり，共通の評価基準とし

て確立したものはまだ決まつていない。

今後粉末メーカー，エーザー間の協力により解決しな ければならない問題である。

\section{3. 製 品 内 容}

当社のタンタル粉末は焼結型電解コンデサ用と治金用 とに大別でき, コンデンサ用は11品種, 治金用として2 品種を開発した。

当社のコンデンサ用粉末の特徵は，1）Solid Capacitor にしたとき耐電圧が高い。2）静電容量が広い範囲 で指定することができ，かつ製品ロット間のバラッキは $\mathrm{CV}$ 值で士 $3 \%$ 以内である。3）流動就よび成型特性を 改良してあり，小型，大型サイズのペレットが安定して 製造できる。また治金用粉末はO $, \mathrm{N}, \mathrm{C}$ などの不純物が 少なく, 金属不純物はきわめて微量で, 造塊後のインゴ ットの品質が Capacitor 用線, 簿, 板に好適である。

第 1 表に当社タンタル粉末のグレードおよび品質規格 走示す。

\section{4. 結言}

当工場泣置的には不便な山の中のひなびた地方工場 ではあるが，他の製品が $\mathrm{t}$ 単位で論じられるところを $\mathrm{kg}$ 単位ですむタンタルの場合には不便さはあまり問題にな らない。むしろ歴史的な地方工場が時代の花形の電子工 業の発展の一翼を担つているといら自負と誇りをもつて
第1表 S. D. K. タンタルメタルパウダー 1. コンデンサ用粉末

\begin{tabular}{l|c|c|c|c}
\hline \hline グレ-ト & $\begin{array}{c}\mathrm{CV} \\
(\mu \mathrm{F} \cdot \mathrm{V} / \mathrm{g})\end{array}$ & L.C. $(\mu \mathrm{A} / \mathrm{g})$ & Loss $(\tan \delta)$ & $\begin{array}{c}\text { S.V. } \\
(\mathrm{V})\end{array}$ \\
\hline DCSL & $1,800 \pm 100$ & $<3.0(270 \mathrm{~V}$ 化成 $)$ & $<0.10$ & $>300$ \\
DCL & $1,500 \pm 100$ & 1.0 & 0.10 & 280 \\
DCSM & $2,400 \pm 100$ & $3.5(270 \mathrm{~V}$ 化成 $)$ & 0.13 & 300 \\
DCM-I & $2,400 \pm 100$ & 1.0 & 0.10 & 280 \\
DCM-II & $2,700 \pm 100$ & 1.0 & 0.12 & 280 \\
DCM-III & $3,000 \pm 100$ & 1.0 & 0.13 & 280 \\
DCH-I & $2,500 \pm 100$ & 1.3 & 0.10 & 250 \\
DCH-II & $2,900 \pm 100$ & 1.3 & 0.10 & 250 \\
DCH-III & $3,100 \pm 100$ & 1.3 & 0.13 & 250 \\
DCUH-I & $>3,600$ & 1.5 & 0.15 & 200 \\
DCUH-II & $>5,000$ & 3.0 & 0.10 & 180 \\
\hline
\end{tabular}

2. 冶金用粉末

\begin{tabular}{|c|c|c|c|c|c|}
\hline \multirow{2}{*}{ ク゚レード } & \multirow{2}{*}{$\begin{array}{c}\text { かさ密度 } \\
\left(\mathrm{g} / \mathrm{cm}^{3}\right)\end{array}$} & \multicolumn{2}{|c|}{ 粒 } & \multicolumn{2}{|c|}{ 分 布 } \\
\hline & & +60 & $-60 \sim 170$ & $-170 \sim 325$ & -325 \\
\hline $\begin{array}{l}\text { DMA } \\
\text { DMB }\end{array}$ & $\begin{array}{l}2.5 \sim 4.5 \\
2.0 \sim 4.0\end{array}$ & $<0.1$ & $\begin{array}{r}45 \sim 55 \\
-\end{array}$ & $\begin{array}{l}30 \sim 45 \\
10 \sim 20\end{array}$ & $\begin{array}{l}<15 \\
<90\end{array}$ \\
\hline
\end{tabular}

個々の作業員が日夜研さんしている。

さらに当工場の場合, 金属ナトリウムの生産も行なつ ているので前述のように, その品質および回収を含めた 原単位の点で非常に優位にある。

今後は，これらの利点を生汃し品質的にさらに向上を 行なうとともにその統一規格化についても業界の協力を 得て進めて行きたい。

、最後に公害対策は発生ガスの回収; 清浄装置, 排液沈 殿沪過槽の設置などタンタルの回収設備と相まつて万全 を期している。

\section{信越化学磯部工場におけるタンタル製鍊}

\section{Processing of Tantalum Metal at Shin-Ttsu Chemical Co.}

正会員平否隆 石

\section{1. 緒 言}

わが国におけるタンタル工業は海外諸国のそれに比べ 企業化の時期は遅く，昭和33～34年にか子，鉱工業技術 試験の補助金の交付を受けた各社が，研究開発に乗り出 したのが始まりである。信越化学におけるタンタル製鍊 は昭和34年 2 月, 東京中央研究所での基礎研究着手に端 を発し，35年 2 月に群馬県安中市の磯部工場内に鉱石か らメタルまでの一貫した中間プラントを建設し小規模な

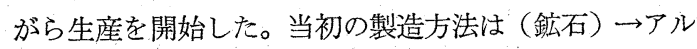
カリ融解一回分抽出 $\rightarrow$ (フルオライド) $\rightarrow$ 熔融塩電解 （メタル）工程による製造方式を採用したが，その後

\footnotetext{
* 信越化学工業株式会社磯部工場金属課（現 武生工場嗮務）
}

生産性, $\mathrm{Ta}$ 歩留り, 純度とくに電子枋料用としてのコ ンデンサ用メタル粉末の諸特性等に問題があることが 分り，昭和 36 年頃から併行して検討を進めてきた（鉱

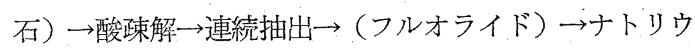
ム還元一 (メタル) 工程によるメタル製造技術開発の確 立によつて，昭和 38 年 6 月に本格的プラントによる一貫 生産体制に移行した。この間収率の向上，品質の改善， 生産性の向上によるコスト低減など幾多の改良改善策が なされ，生産能力も今日ではタンタルフルオライド $2.0 \mathrm{t}$ /月，タンタルオキサイド $0.5 \mathrm{t} /$ 月, メタル $0.7 \mathrm{t} /$ 月に達し 品質面でも飛躍的な進歩をみるにいたつた。しかしなが ら，後述のよらにわが国のタンタル工業は予想に反し需 要の伸び悩みと鈗石事情の悪化などから各社ともに経済 